\title{
Socio-Economic Impacts of Hyena Predation on Livestock around Lake Nakuru National Park and Soysambu Conservancy, Kenya
}

\author{
Christine Chepngeno Koskey ${ }^{1 *}$, Dickson L. Makanji ${ }^{1}{ }^{*}$, Christine E. Wilkinson ${ }^{2}$, \\ George W. Eshiamwata ${ }^{3}$ \\ ${ }^{1}$ Department of Natural Resources, Egerton University, Egerton, Kenya \\ ${ }^{2}$ Department of Environmental Sciences, Policy, and Management, University of California, Berkeley, CA, USA \\ ${ }^{3}$ Natural Sciences, Kenya National Commission for UNESCO, Nairobi, Kenya \\ Email: *chepngeno2013@gmail.com, *d.makanji@egerton.ac.ke
}

How to cite this paper: Koskey, C. C., Makanji, D. L., Wilkinson, C. E., \& Eshiamwata, G. W. (2021). Socio-Economic Impacts of Hyena Predation on Livestock around Lake Nakuru National Park and Soysambu Conservancy, Kenya. Open Journal of Social Sciences, 9, 411-425.

https://doi.org/10.4236/jss.2021.99029

Received: June 29, 2021

Accepted: September 14, 2021

Published: September 17, 2021

Copyright $\odot 2021$ by author(s) and Scientific Research Publishing Inc. This work is licensed under the Creative Commons Attribution International License (CC BY 4.0).

http://creativecommons.org/licenses/by/4.0/

\begin{abstract}
Human-wildlife conflicts (HWCs) may arise when expanding human populations and activities overlap or compete for space and resources with wildlife. They may also be due to growing wildlife populations that encroach on human settlements or other areas of human development. Forms of human-wildlife conflict include livestock predation, harassment, property damage, habitat loss due to human activities, and interpersonal conflict over wildlife issues resulting in injuries or mortalities. The spotted hyena (Crocuta crocuta) is among animals involved in livestock predation for many reasons thus leading to conflicts with livestock owners. This study focused on the causes of human-hyena conflict and the socio-economic impacts of hyena predation on livestock. The study adopted a survey research design. Data were collected using an interview schedule and key informant meetings, targeting different segments of the community. Purposive sampling was employed in data collection. Data were analyzed using descriptive and inferential statistics. The results showed that poor park fencing is the major cause of human hyena conflict with a representation of $40 \%$ (125 respondents). Despite the fact that LNNP is fenced, community members still raise complaints about porosity. On the other hand, $60 \%$ of Soysambu Conservancy is not fenced, potentially giving hyenas freedom to move from the conservancy to the community. The total estimated cost that is lost to hyena predation in this region as per the responses received in the surveys is approximately $\$ 74,740$ USD annually. A total of 1020 shoats were either wounded or killed. Our results suggest that one potential solution is to completely fence both protected areas and maintain the fences to reduce if not halt human-hyena conflicts and perceptions of hyenas as a conflict-
\end{abstract}


prone species.

\section{Keywords}

Human Hyena Conflict, Predation, Mortalities

\section{Introduction}

HWC is defined as interactions between humans and wildlife where negative consequences, whether perceived or real, exist for one or both parties (Decker, Lauber, \& Siemer, 2002; Peterson et al., 2010). It poses one of the greatest challenges to conservation and livelihoods globally, although the form and impacts vary spatially and temporally. It is a significantly growing conservation problem around the world (Nyhus, Osofsky, Ferraro, Madden, \& Fischer, 2005). This conflict occurs where there is interaction between wildlife and human beings which is currently affecting the suburban and urban areas especially in regard to livestock depredation (Pack et al., 2013; Anand \& Radhakrishna, 2017). While wildlife species are important from a socio-economic perspective (Newsome, Dowling, \& Moore, 2005), human-wildlife conflict is considered to be one of the threats driving species to extinction (Hall, 2015). Globally, wildlife has been decreasing for the last 40 years by as much as $58 \%$ due to human activities such as wildlife trade, pollution, climate change, and habitat loss through deforestation (Hall, 2015). Incidences of HWC have been increasing due to an increase in human populations encroaching upon wildlife habitat, including dispersal corridors previously used by wide ranging or migratory wildlife species (Le Bel et al., 2011).

HWC has attracted the attention of wildlife biologists, managers, and ecologists because it has become a global issue which has led to extinction of some wildlife due to conflicts not being well-managed (Hill, Osborn, \& Plumptre, 2002).

Human communities have suffered from livestock predation, harassment by wildlife, and property damage in many areas of the world (Messmer, 2000). There are also interpersonal conflicts over wildlife issues undermining human welfare, health, and safety, and wildlife may also have negative economic and social impacts (Messmer, 2000). Research has shown that human-wildlife conflict should be managed in such a way that it does not jeopardize wildlife conservation objectives nor endanger human existence (Dickman, 2010; Anand \& Radhakrishna, 2017). How people perceive conflicts not only depends on the destruction wild animals are causing but also on socio-cultural factors (Dickman, 2010; Anand \& Radhakrishna, 2017). For instance, attitude, education level, belief and value systems, thus, when measures are put in place to control the conflicts, success can sometimes be minimal because top-down policy makers may fail to understand the complexity of human-wildlife interactions.

Despite the fact that HWC is a global phenomenon, the extent, magnitude, 
and impacts vary from one region to another (Pack, Golden, \& Walker, 2013). In Kenya the impact of human wildlife conflict especially predation of livestock by carnivores is huge. This varies with the neighboring countries like Tanzania and Uganda. African lion (Panthera leo) and spotted hyena (Crocuta crocuta) may pose many socio-economic challenges through attacks on livestock. One way people respond to such a problem is to kill the problematic wildlife (Dickman, Hazzah, Carbone, \& Durant, 2014). In Maasai Mara National Park, people responded to the lions attack buy killing them or poisoning them. In Soysambu Conservancy, snares were put along the demarcations of the Soysambu so as to trap and kill the hyenas and other animals that cross over to the community. Additionally, perceptions of people towards wildlife can be influenced by the threats that the wild animals are posing and also the susceptibility of those animals towards property damages (Dickman, 2010). Many people especially in Kenya do not like carnivores to be conserved due to the huge losses that they cause to humans especially on livestock predation.

Human-wildlife conflict leads to socio-economic impacts locally, nationally, regionally, and globally as humans move from one place to another. People who are sedentary are affected as well as those who move from one place to another as tourists or pastoralists. Large mammalian carnivores (lions, leopards, cheetahs, spotted hyenas and wild dogs), larger herbivores (elephants, buffalo and hippopotamus), and crocodiles are traditionally seen as the animals representing the greatest threat to humans and responsible for the majority of human-wildlife conflicts (Masago, 2018). Large animals like lions, leopards, wild dogs, and spotted hyena, cause the greatest impacts in terms of human-wildlife conflicts leading to minor, serious injuries, and even death. According to Wang and Macdonald (2006), livestock predation by carnivores in Jigme Singye Wangchuck National Park, is conspicuous. The annual mean livestock loss faced by farmers is almost 1.29 head of stock leading to an economic loss amounting to USD 12,252 of which leopard and tiger kills accounted for $82 \%$ (US\$ 10,047). The majority of tiger kills were cows, which in essence farmers keep for milk production and multiplication of future herds. A study undertaken in Web Valley, Bale Mountains National Park in Ethiopia showed that a total number of 704 livestock were killed by wild carnivores over a 3-year period, causing a loss of potential revenue of USD 12 per year per household in a compounded interest. Spotted hyenas were reported to be responsible for most livestock predation. According to this study, hyenas killed all livestock types (horses, donkeys, mules, cattle, goats and sheep) whereas leopards, common jackals and servals (medium wildcats) killed mostly goats and sheep (Atickem, Williams, Bekele, \& Thirgood, 2010).

In Kenya, about $80 \%$ of the land is arid or semi-arid, and $10 \%$ consists of woodlands, forests, national reserves, and game reserves (Esikuri 1998). Additionally, the country has 348 wildlife protected areas, which cover 12.7 percent of the total land in the country, approximated to be $75,238 \mathrm{~km}^{2}$ (Esikuri, 1998). Within these areas, there are 350 species of mammals, 6500 plant species, and 1000 bird species, giving Kenya the second highest wildlife diversity of all Afri- 
can countries (Kamau, Mbaria, \& Koichi, 2012). Almost $60 \%$ of wildlife in the country is found outside of the formal protected areas, thus leading to increasing interactions between human and wildlife (Carter et al., 2012). Thus, the potential for conflict is always present due to these interactions.

According to Muruthi (2005) and KWS (1992), the main wildlife-related problems for people living in Kenyan rangelands are competition for water and grazing, increased risk of livestock diseases, crop damage, livestock predation, and loss of human life. Lake Nakuru National Park (LNNP) is a world class national park which has been described as "the lake of million flamingoes", "the world ornithological spectacle", and is the bedrock to various tourism destinations (Raini, 2009). However, the areas near LNNP have been heavily settled, urbanized, industrialized, and highly cultivated, which may be contributing to conflict between humans and wildlife in this area. Over the last 70 years, various human activities have been found to be limiting the movement of large mammals in and around LNNP (Jumba, Kisia, \& Kock, 2007). Additionally, the conservation of LNNP is driven by politics at the national level and even at the local level since 1991 (Daniels \& Basset, 2002). In addition to this, Lake Nakuru National Park is among the most visited protected areas in Kenya (Sindiga, 1995; Daniels \& Bassett, 2002). On the other hand, Soysambu Conservancy, adjacent to LNNP, is a privately-owned wildlife conservancy (Muller, 2018). Its mission involves conserving wildlife and promoting the coexistence of wildlife with livestock, which is relevant to today's modern society in Kenya

This study therefore helps in understanding the main causes of human-hyena conflict and the socio-economic impacts of hyena predation on livestock. Moreover, it elucidates the total cost lost to hyena through livestock predation.

\section{Materials and Methods}

The study was carried out in 9 villages (Figure 1), that border Lake Nakuru National Park $\left(188 \mathrm{~km}^{2}\right)$ and Soysambu Conservancy $\left(199 \mathrm{~km}^{2}\right)$. LNNP was created in 1961 and is an important bird area especially for the flamingos. It is found in Nakuru County, approximately $160 \mathrm{~km}$ northwest of Nairobi, and lies at an altitude of $1952 \mathrm{~m}$ above sea level. Soysambu Conservancy, which is adjacent to the Lake Nakuru National Park, lies 1700 m above sea level (Daniels \& Bassett, 2002; Musimbi, 2013). Lake Nakuru National Park and Soysambu Conservancy lie within $36^{\circ} 05^{\prime} \mathrm{E}$ and $0^{\circ} 24^{\prime} \mathrm{S}$. Soysambu Conservancy is to the east of LNNP and shares a boundary of $12.1 \mathrm{~km}$. Though the livestock ranch in Soysambu Conservancy is from the colonial era, the conservancy was created in the year 2007 to serve as an entity of conserving the flora, fauna, and scenery.

\section{Data collection and analysis}

Sampling: Out of 432 questionnaires, 378 respondents participated in the interview providing their views as stated in the results section. The questionnaires had closed and open-ended questions, allowing people to respond with additional information outside of what you included in the survey. 


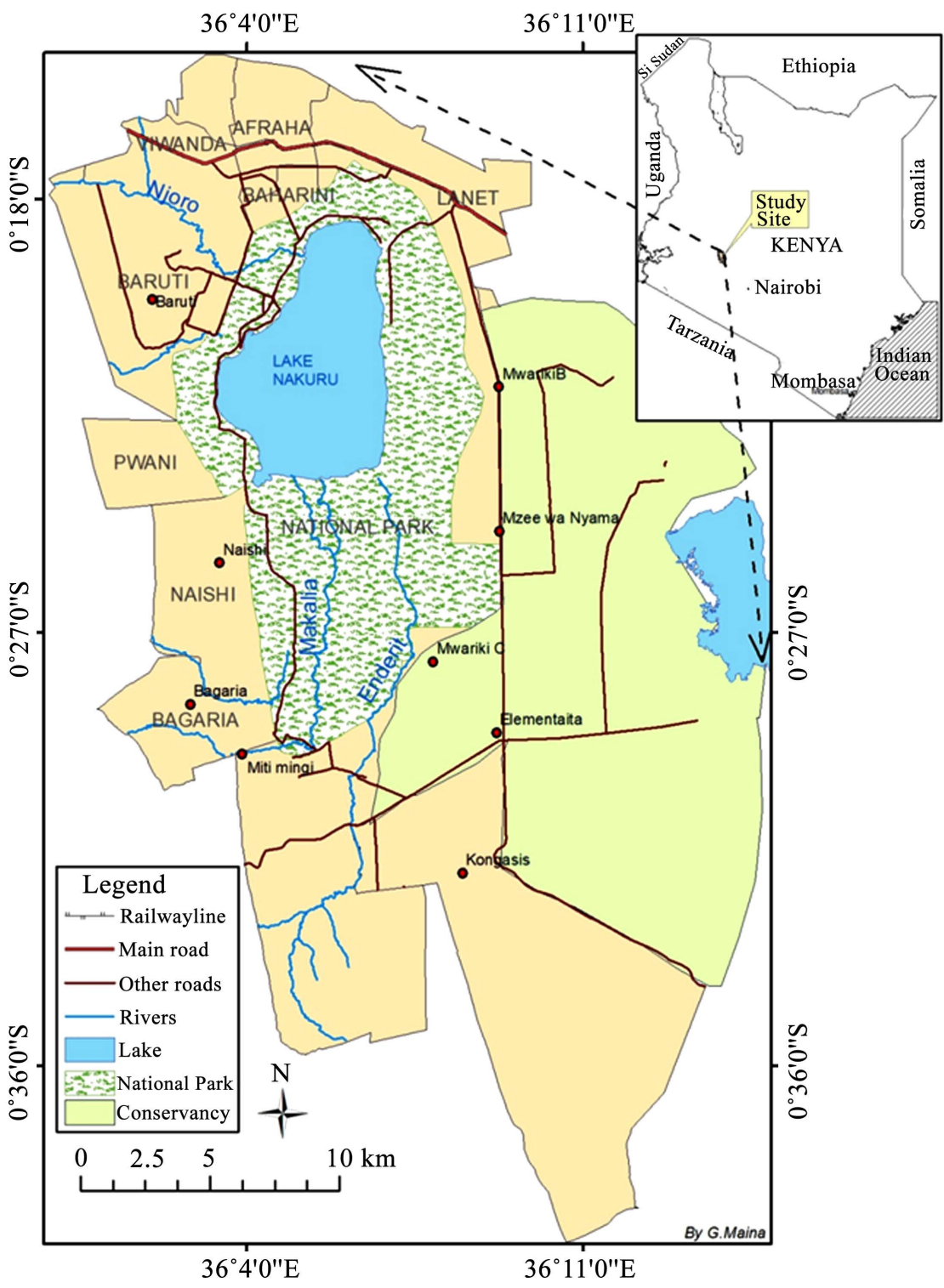

Figure 1. Study areas and villages around Lake Nakuru National Park and Soysambu conservancy.

\section{Sample size determination}

The sample size was determined by following what Conroy (2006), documented about sample size calculation. Before calculating the sample size, there are two factors to be considered; degree of precision and also the uncertainty of the sample. A larger sample size is better for an unknown population. In such cases, when using the large population more than 5000 people 384 people are to be sampled in order to attain the $95 \%$ power of the data which is $\pm 5 \%$ Confidence Interval (CI). Additionally, according to Israel (1992) on sample size determination for a large unknown population should adapt the following formula.

$$
n_{o}=Z^{2} P Q / e^{2}
$$

where: 
$n_{\mathrm{o}}$ is the sample size,

$Z^{2}$ is abscissa of the normal curve,

$P$ is estimated proportion,

$Q$ is $(1-P)$,

$e$ is the desired level of precision.

Additionally, the subgroups, which are men and women, at different ages with different educational levels, are represented by $10 \%$ of sample $\left(384{ }^{*} 10 / 100=38\right.$ respondents). When calculated it results to 38 respondents under $\pm 20 \%$ CI. A total of 10 respondents were added to take care of random error. The result from the calculation is $432(384+38+10=432)$ people to be sampled which was broken down to 48 per large village jurisdiction that is 24 men and 24 women to be split over to two days giving a total of at least 9 villages randomly picked within $8 \mathrm{~km}$ of LNNP and Soysambu Conservancy.

\section{Sampling Procedure}

The study employed purposive sampling technique which was used to select respondents from the study area. The population was then divided into groups (villages which are Mzee wanyama, Miti Mingi, Mwariki B, Mwariki C, Naishi, Baruti, Kongasis, Bagaria and the Elementaita) which are the villages between Soysambu Conservancy and the Lake Nakuru National Park. The individuals within the groups were chosen by picking them semi-randomly with the help of chiefs, assistant chiefs and the village elders.

Study design and data analysis: The study employed a survey design which involved a social survey. This survey was conducted to obtain data on the main causes of conflicts between the spotted hyena and the local community. Data that were generated were cleaned to detect errors and omissions. Data from interviews (using the Android application Open Data Kit) were analyzed using SPSS software (Statistical Package for Social Sciences) version 24 and Microsoft Excel, and the results were displayed in charts, frequency distribution diagrams, statistical tables, and descriptive statements basing on the research objectives.

\section{Results and Discussions}

\subsection{Causes of Human Hyena Conflict}

The causes of attacks were categorized into four categories: hyena food shortage, poor park fencing, poor boma fencing, and human encroachment into wildlife space. Most of the respondents reported that they perceived poor park fencing to be the major cause of attack (40\%: 125 respondents). At least $80 \%$ of LNNP is fenced with an 11-wire high-tensile electric fence. Despite the fact that LNNP is fenced, community members still raise complaints about the park being poorly fenced. On the other hand, about 1/3 of Soysambu Conservancy's boundary is not fenced, potentially allowing hyenas the ability to move from the conservancy to the community. The respondents suggested the second cause of human hyena conflict as hyena food shortage with a representation of 36\% (221 respondents). 52 respondents $(8 \%)$ commented that human encroachment was also another 
cause of HHC.

Apart from the four categories of causes of $\mathrm{HHC}$, respondents noted other causes, such as poor security from KWS in terms of the number of rangers. Additionally the respondents testified that most of their livestock get to the nighttime bomas late in the evening, and on the way home they are attacked by hyenas. According to the respondents, hyenas are perceived to be greedy, and to always hide in the nearby bushes that are near their homesteads giving them an advantage to attack their livestock. The respondents also reported that hyenas in the area are many and because of this hyenas compete with the scarce resources with other cats forcing them to get out of the park for livestock predation. (Figure 2)

\subsection{Socio-Economic Impacts of Hyena Predation}

In regard to hyena predation in the villages around Lake Nakuru National Park and Soysambu Conservancy, shoats had a higher number of predation compared to cattle and donkeys (Figure 3). A total of 1020 were either wounded or killed (Table 1). Of these, 777 shoats were killed by hyenas, 75 were injured and 7 shoats were killed by unknown animals. Socially hyena attacks have also impacted people around Lake Nakuru National Parks and Soysambu Conservancy. The respondents stated that they have lost a lot of livestock to hyenas that had led to wealth drain and at times fear from walking around late in the evening.

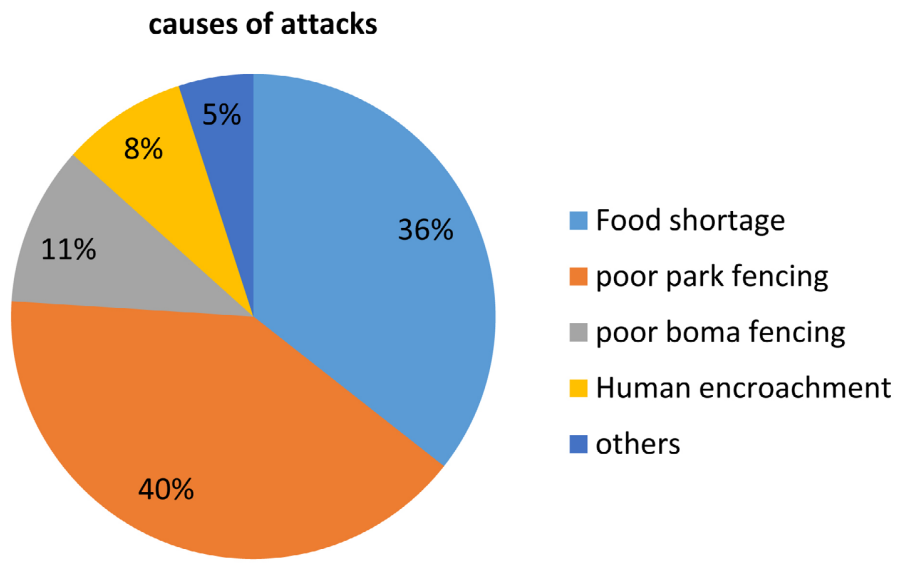

Figure 2. Causes of human hyena conflict.

Table 1. Total cost lost to hyena predation.

\begin{tabular}{cccccc}
\hline $\begin{array}{c}\text { Livestock } \\
\text { Type }\end{array}$ & Injured & Killed & $\begin{array}{c}\text { Total } \\
\text { number }\end{array}$ & $\begin{array}{c}\text { Value per } \\
\text { animal (USD) }\end{array}$ & $\begin{array}{c}\text { Total cost lost (USD) } \\
\text { Total value in USD }\end{array}$ \\
\hline Dogs & 39 & 29 & 68 & - & \\
Shoats & 75 & 777 & 852 & 60 & 52,120 \\
Cattle & 28 & 58 & 86 & 250 & 21,500 \\
Donkey & 4 & 10 & 14 & 80 & 1120 \\
Total & & & & & 74,740 \\
\hline
\end{tabular}




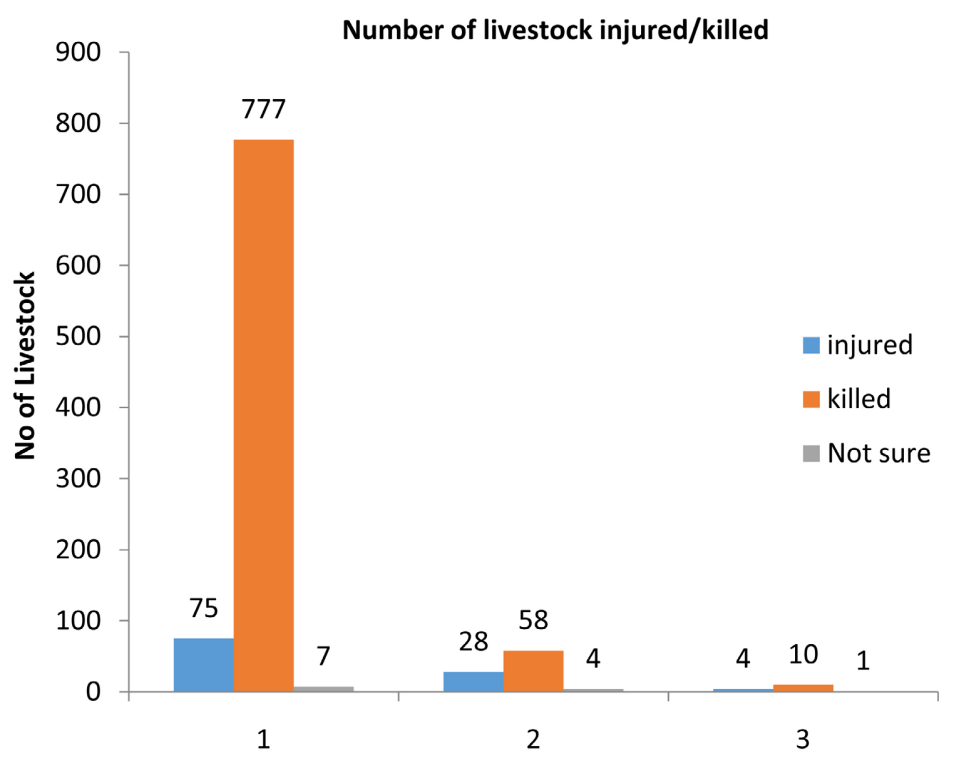

Figure 3. The number of livestock injured and killed by hyenas in the study area.

\subsection{The Total Number of Livestock Lost and Their Monetary Value}

The monetary values for these livestock were determined using the current market price as per what the respondents reported. The total estimated cost that is lost to hyena predation in this region as per the responses received in the surveys is approximately $\$ 74,740$ USD annually (from the respondents).

The number of dogs lost to hyena predation was 68 . Of these, 39 were injured and 29 were killed. Unfortunately, according to KWS dogs are not compensated and that is the reason there is no money for compensating dogs therefore, getting the total cost lost is a problem.

\section{Local community's perception towards hyena conservation}

The perception for hyena conservation in these villages seems to be positive because the respondents who support hyena conservation are more than those who are against the conservation. Those who supported (244 respondents) gave different reasons for hyena conservation, such as money from ecotourism, ecological reasons, cultural reasons and others. Among the other reasons that the respondents gave out were witchcraft. This is because the hyenas are used by certain cultures in practicing witchcraft. Additionally, they are also used as totems, therefore should be conserved. Besides, the respondents indicated that hyena should be conserved for sustainability, educational researches, ecosystem balance and for future generation to see and identify its behaviour and importance. Moreover hyena conservation creates job opportunity for youths as tour guides and also wildlife rangers. Furthermore, hyenas as considered to be beautiful therefore adding up to the aesthetic value of nature. Others stated that hyenas are God's creation and therefore should be conserved. They also pointed out that hyenas provides security and helps in controlling conflict arising from herbivores and humans as they help in predating on herbivores. On the other hand, 112 respon- 
dents said that there is no need to conserve the hyena giving the following reasons: hyenas are a sign of bad omen, they attack livestock, attack people, are noisy animals with bad sounds and of no importance, they are dangerous and worst enemies of the people, they are ugly, thieves with no manners and brings about losses which cannot be compensated. Despite the fact that there were those for conservation and those who were against the conservation, 4 respondents had no opinion about the conservation. (Figure 4)

\section{Reasons for conserving the hyenas}

The respondents who were for the conservation gave different reasons for the conservation. 219 respondents said that it is good to conserve hyenas for money from ecotourism, 115 were for ecological reasons and 39 respondents said that it is good to conserve hyenas for cultural reasons. In addition to this, 28 respondents gave other reasons for conserving hyenas. They said that it is good to conserve hyenas for education, conflict control, and aesthetic value, sustainability for the next generation and also for job opportunity. (Figure 5)

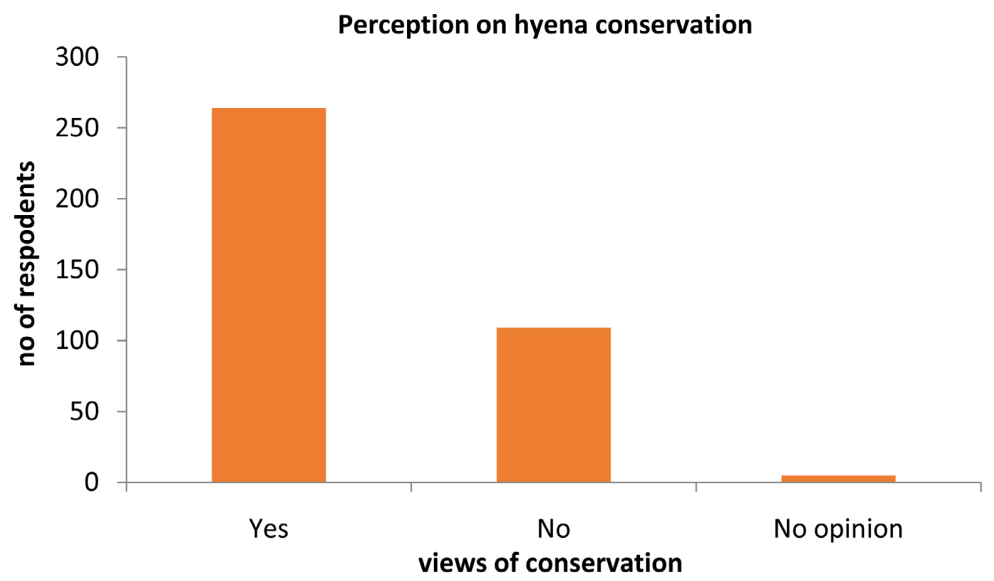

Figure 4. Local community's perceptions towards hyena conservation in LNNP and Soysambu conservancy.

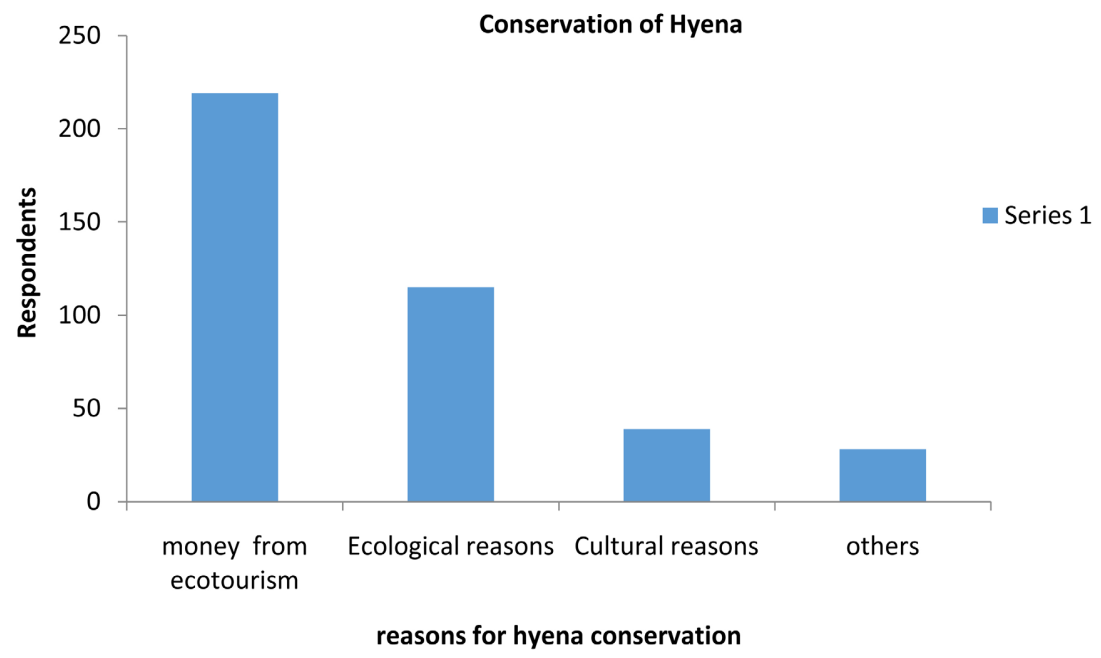

Figure 5. Reasons for hyena conservation. 


\section{Reasons for not conserving hyenas}

Majority of the respondents (50\%) of the respondents suggested that there was no need to conserve hyenas. These respondents said that spotted hyenas (Crocuta crocuta) attacks their livestock and that is the main reason why they did not like hyenas to be conserved in the park and the conservancy. Local community suggested that hyenas should be transferred to other parks where human population is a bit low. Among the 50\% respondents, $9 \%$ gave more other reasons showing why hyenas should not be conserved. The reasons were; hyenas are very noisy and they have bad sound that disturbs the whole village and it is hard to sleep unless you are used to. They also said that hyenas have no importance therefore, there is no need for conservation. Hyenas being enemies, dangerous, disturbing animals, ugly animals, thieves and animals with no manners were also among the other reasons that were highlighted by the local community. (Figure 6)

\subsection{Demographic Variables and Relationship with Hyena Conservation}

To test whether there were differences in each group, chi square test was used with $\alpha=0.5$ as criterion for significance. Conservation of hyena also depended with the demographic characteristics of the respondents, education, age, occupation and ethnicity (Table 2). According to the results from the analysis of the collected data showed that there is a significance in hyena conservation with the

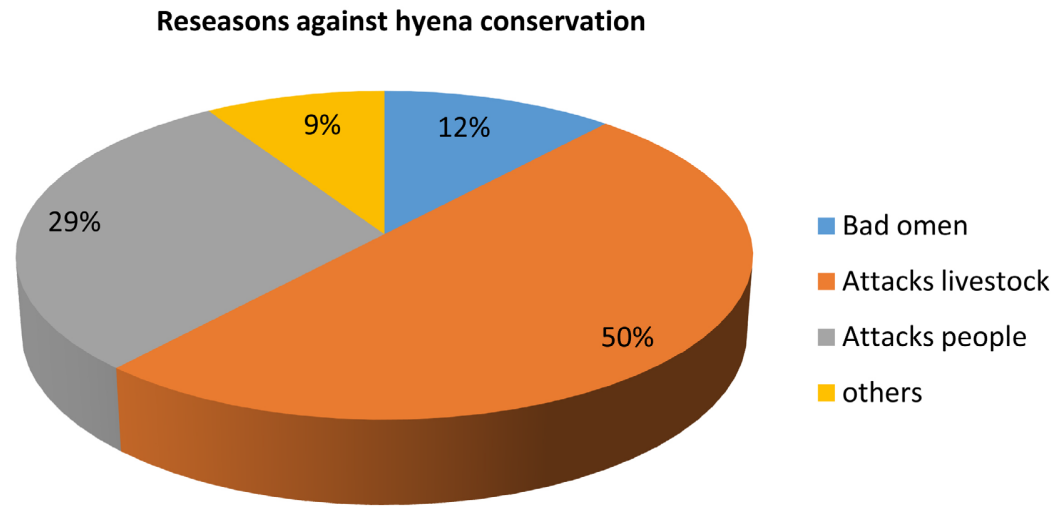

Figure 6. Reason against hyena conservation.

Table 2. Showing demographic relationships with hyena conservation.

\begin{tabular}{|c|c|c|c|c|c|c|c|c|c|c|c|c|}
\hline & \multicolumn{2}{|c|}{ age } & \multicolumn{2}{|c|}{ Education } & \multicolumn{2}{|c|}{ Occupation } & \multicolumn{2}{|c|}{ Ethnicity } & \multicolumn{2}{|c|}{ Religion } & \multicolumn{2}{|c|}{ Gender } \\
\hline & Value & $\begin{array}{c}\text { Asymp. } \\
\text { Sig. } \\
\text { (2-sided) }\end{array}$ & Value & $\begin{array}{c}\text { Asymp. } \\
\text { Sig. } \\
\text { (2-sided) }\end{array}$ & Value & $\begin{array}{c}\text { Asymp. } \\
\text { Sig. } \\
\text { (2-sided) }\end{array}$ & Value & $\begin{array}{c}\text { Asymp. } \\
\text { Sig. } \\
\text { (2-sided) }\end{array}$ & Value & $\begin{array}{c}\text { Asymp. } \\
\text { Sig. } \\
\text { (2-sided) }\end{array}$ & Value & $\begin{array}{c}\text { Asymp. } \\
\text { Sig. } \\
\text { (2-sided) }\end{array}$ \\
\hline $\begin{array}{l}\text { Pearson } \\
\text { Chi-Square }\end{array}$ & $12.294^{\mathrm{a}}$ & 0.422 & $44.961^{\mathrm{a}}$ & 0.000 & $77.473^{\mathrm{a}}$ & 0.000 & $45.171^{\mathrm{a}}$ & 0.001 & $0.738^{\mathrm{a}}$ & 0.994 & $2.140^{\mathrm{a}}$ & 0.343 \\
\hline $\begin{array}{c}\text { Likelihood } \\
\text { Ratio }\end{array}$ & 12.149 & 0.434 & 41.047 & 0.001 & 38.028 & 0.060 & 38.325 & 0.008 & 1.30 & 0.972 & 2.263 & 0.323 \\
\hline
\end{tabular}


education (chi square $44.961, p=0.000$ ) age (chi square $12.294, p=0.422$ ), occupation (chi square 77.473, $p=0.000$ ) and ethnicity (chi square $45.171, p=$ 0.001 ). On the other hand, conservation of hyena corresponding to gender (chi square, 2.140, $p=0.343$ ) and religion (chi square, $0.743, p=0.994$ ) are not significant therefore conservation of hyena is not based on gender nor religion in villages around Lake Nakuru National Park and Soysambu Conservancy.

\section{Discussion}

\section{Causes of human hyena conflict}

Most of the interviewees who live adjacent to Lake Nakuru National Park and Soysambu Conservancy suggested that poor park fencing is the major cause of human hyena conflict This is because the park may not have the resources for frequent enough monitoring and maintenance (Wilkinson et al., in review). On the hand, Soysambu Conservancy is very open especially to the east side and some places in the southern part. This explains why human -hyena conflicts are still rampant. On top of this, people kill and injure hyenas because they freely move out of the park. This has prompted the community members near Soysambu Conservancy to put up snares to either kill or injure the hyenas. This is contrary to Ocholla et al.'s (2013) assertion that the major cause of human wildlife conflict generally is human population growth and conversion of land to agriculture. Human populations have recently raised that have forced wildlife habitat be converted to crop lands, grazing lands. To control this small protected areas require fences in order to not be further encroached upon by people. Hyenas are found to have a strange behavior similar to that of cercopithecine primates since fencing does not completely deter them (Drea \& Carter, 2009). In such cases where there is a fence they do excavation on the ground that gives them a way out to the community or local people bordering the protected areas. Still, the community complains that a fence is a major contributing factor towards humanhyena conflicts.

According to the respondents the total estimated value that is lost to hyena predation in this region is approximately $\$ 74,740$ USD annually. The Indiantrans Himalayan communities reported an economic loss of $\$ 15,418$ due to predation which is equivalent to $\$ 128$ loss per family per year and in Kenya, at least 87,498 USD is lost to livestock predation annually (Kissui, 2008), and Zimbabwe as well recorded economic loss averaging $\$ 13 \%$ or $12 \%$ of each household's net annual income (Butler, 2000). This shows that the impact of livestock predation is huge and is globally felt and experienced. In Ethiopia as well, in the year 2005 to 2009 , livestock losses due to predation amounted to 492 heads over 5 years; an annual mean of $0.6 \%$ worth US\$7042 (Abay, Bauer, Gebrihiwot, \& Deckers, 2011).

How people perceive hyena conservation in the study area was positive even though they caused a lot of destruction especially to livestock. Many of the respondents were reporting that failure to conserve hyena may lead to poor ecology 
and also the next generation may not be able see the hyenas. According to Oli, Taylor and Rogers, (1994); de Pinho, Grilo, Boone, Galvin and Snodgrass, (2014), people in Nepal and Kenya have negative attitude towards carnivore conservation (hyena and leopards) to the extent that they would wish to eradicate or minimize their number. According to Liu, McShea, Garshelis, Zhu, Wang and Shao (2011), different people have different perceptions on wildlife. In China only $6.5 \%$ indicated that they liked bears, whereas $50.2 \%$ disliked bears and $43.2 \%$ offered no clear opinion. The liking of bears depended significantly on the presence of bears near their village, villagers' age, knowledge level about bears, and profession. This is also depicted in the results of perception of communities around Lake Nakuru National Park that hyena conservation depends with age, occupation, educational level and ethnicity.

\section{Conclusion}

Human-hyena conflict (or perceptions thereof) has caused a lot of havoc to livestock in Lake Nakuru National park and Soysambu Conservancy. We present the first known analysis of socio-economic impacts of hyena predation on livestock, which showed that shoats were the most highly preyed upon livestock species. Although depredated cows were few, their overall economic loss is high compared to shoats and dogs. The issue of poor park fencing is a major cause of hyena attacks that has led to conflicts between the community and the wildlife. The other perceived causes of human-hyena conflict were lack of food for hyenas, poor fencing around bomas and human encroachment on hyena habitat. These results point to a need, or at least a public desire, to erect robust fences around both protected areas to reduce interactions between people and wildlife in Lake Nakuru National Park and Soysambu Conservancy. However, in order to reduce human-hyena conflicts, the conservancy and national park administrations may also consider the creation of awareness on the importance of hyena conservation.

It is showing the interest of the community towards hyena conservation and if laws will be implemented accordingly, people living adjacent to parks will benefit and the level of conflict will subside.

\section{Acknowledgements}

We express our gratitude to KWS (Lake Nakuru National Park) and Soysambu Conservancy for their support during data collection. We thank the National Commission for Science, Technology, and Innovation for permission to conduct this research (NACOSTI/P/18/83301/21274). This work was supported by the National Geographic Society (Grant EC 339C-18) and RUFORUM through "Transforming African Agricultural Universities to Meaningfully Contribute to Africa's Growth and Development project" (TagDev) of Egerton University funded by Master Card Foundation. Christine Eleanor Wilkinson was supported by The National Science Foundation Graduate Research Fellowship for the duration of this 
study. Last but not least, we acknowledge the cooperation from the local Chiefs and local communities, and the respondents whose support made it possible for administration of the questionnaires to be done.

\section{Data Availability}

The data used to support the findings of this study are available from the corresponding author upon request

\section{Conflicts of Interest}

The authors declared that there are no conflicts of interest

\section{Credit Authorship Statement}

Christine Koskey: Conceptualization, Methodology, Software Data curation, Writing-Original draft preparation. Supervision. Dr. Dickson Makanji and Dr. George. Eshiamwata: Software, Validation. Writing-Dr. Dickson Makanji and Dr. George Eshiamwata Reviewing and Editing Christine Wilkinson.

\section{References}

Abay, G. Y., Bauer, H., Gebrihiwot, K., \& Deckers, J. (2011). Peri-Urban Spotted Hyena (Crocutacrocuta) in Northern Ethiopia: Diet, Economic Impact, and Abundance. European Journal of Wildlife Research, 57, 759-765. https://doi.org/10.1007/s10344-010-0484-8

Anand, S., \& Radhakrishna, S. (2017). Investigating Trends in Human-Wildlife Conflict: Is Conflict Escalation Real or Imagined? Journal of Asia-Pacific Biodiversity, 10, 154 161. https://doi.org/10.1016/j.japb.2017.02.003

Atickem, A., Williams, S., Bekele, A., \& Thirgood, S. (2010). Livestock Predation in the Bale Mountains, Ethiopia. African Journal of Ecology, 48, 1076-1082. https://doi.org/10.1111/j.1365-2028.2010.01214.x

Butler, J. R. A. (2000). The Economic Costs of Wildlife Predation on Livestock in Gokwe Communal Land, Zimbabwe. African Journal of Ecology, 38, 23-30. https://doi.org/10.1046/j.1365-2028.2000.00209.x

Carter, N. H., Shrestha, B. K., Karki, J. B., Pradhan, N. M. B., \& Liu, J. (2012). Coexistence between Wildlife and Humans at Fine Spatial Scales. Proceedings of the National Academy of Sciences, 109, 15360-15365. https://doi.org/10.1073/pnas.1210490109

Conroy, R. (2006). Sample Size: A Rough Guide.

Daniels, R., \& Bassett, T. J. (2002). The Spaces of Conservation and Development around Lake Nakuru National Park, Kenya. The Professional Geographer, 54, 481-490. https://doi.org/10.1111/0033-0124.00344

de Pinho, J. R., Grilo, C., Boone, R. B., Galvin, K. A., \& Snodgrass, J. G. (2014). Influence of Aesthetic Appreciation of Wildlife Species on Attitudes towards Their Conservation in Kenyan Agropastoralist Communities. PLoS ONE, 9, e88842. https://doi.org/10.1371/journal.pone.0088842

Decker, D. J., Lauber, T. B., \& Siemer, W. F. (2002). Human-Wildlife Conflict Management.

Dickman, A. J. (2010). Complexities of Conflict: The Importance of Considering Social Factors for Effectively Resolving Human-Wildlife Conflict. Animal Conservation, 13, 458- 
466. https://doi.org/10.1111/j.1469-1795.2010.00368.x

Dickman, A. J., Hazzah, L., Carbone, C., \& Durant, S. M. (2014). Carnivores, Culture and "Contagious Conflict": Multiple Factors Influence Perceived Problems with Carnivores in Tanzania's Ruaha Landscape. Biological Conservation, 178, 19-27. https://doi.org/10.1016/j.biocon.2014.07.011

Drea, C. M., \& Carter, A. N. (2009). Cooperative Problem Solving in a Social Carnivore. Animal Behaviour, 78, 967-977. https://doi.org/10.1016/j.anbehav.2009.06.030

Esikuri, E. E. (1998). Spatial-Temporal Effects of Land Use Changes in a Savanna Wildlife Area of Kenya. Doctoral Dissertation, Virginia Tech.

Hall, C. M. (2015). Loving Nature to Death: Tourism Consumption, Biodiversity Loss and the Anthropocene. In Tourism and the Anthropocene (pp. 52-74). Routledge.

Hill, C., Osborn, F., \& Plumptre, A. J. (2002). Human-Wildlife Conflict: Identifying the Problem and Possible Solutions.

Israel, G. D. (1992). Determining Sample Size.

Jumba, I. O., Kisia, S. M., \& Kock, R. (2007). Animal Health Problems Attributed to Environmental Contamination in Lake Nakuru National Park, Kenya: A Case Study on Heavy Metal Poisoning in the Waterbuck Kobus ellipsiprymnus Defassa (Ruppel 1835). Archives of Environmental Contamination and Toxicology, 52, 270-281. https://doi.org/10.1007/s00244-005-0241-2

Kamau, P. K., Mbaria, J. G., \& Koichi, K. (2012). Human-Wildlife Conflict in Kenya.

Kissui, B. M. (2008). Livestock Predation by Lions, Leopards, Spotted Hyenas, and Their Vulnerability to Retaliatory Killing in the Maasai Steppe, Tanzania. Animal Conservation, 11, 422-432. https://doi.org/10.1111/j.1469-1795.2008.00199.x

KWS (1992). Kenya Wildlife Service: Report of the Proceedings of Strategic Planning Workshop for the Community Wildlife Service Department, 29th June1 st July 1992. Nairobi Kenya.

Le Bel, S., Murwira, A., Mukamuri, B., Czudek, R., Taylor, R., \& La Grange, M. (2011). Human Wildlife Conflicts in Southern Africa: Riding the Whirl Wind in Mozambique and in Zimbabwe. In The Importance of Biological Interactions in the Study of Biodiversity. InTech. https://doi.org/10.5772/23682

Liu, F., McShea, W. J., Garshelis, D. L., Zhu, X., Wang, D., \& Shao, L. (2011). HumanWildlife Conflicts Influence Attitudes But Not Necessarily Behaviors: Factors Driving the Poaching of Bears in China. Biological Conservation, 144, 538-547. https://doi.org/10.1016/j.biocon.2010.10.009

Masago, J. M. O. (2018). The Impact of Human Wildlife Conflict on Acquisition of Quality Education in Narok West Sub County, Kenya.

Messmer, T. A. (2000). The Emergence of Human-Wildlife Conflict Management: Turning Challenges into Opportunities. International Biodeterioration \& Biodegradation, 45, 97-102. https://doi.org/10.1016/S0964-8305(00)00045-7

Muller, Z. (2018). Population Structure of Giraffes Is Affected by Management in the Great Rift Valley, Kenya. PloS One, 13, e0189678.

https://doi.org/10.1371/journal.pone.0189678

Muruthi, P. M. (2005). Human-Wildlife Conflicts: Lessons Learnt from AWF's African Heartlands. AWF Working Papers, July 2005, African Wildlife Foundation.

Musimbi, M. (2013). Factors Influencing Human-Wildlife Conflict in Communities around the Park: A Case of Lake Nakuru National Park, Kenya. Masters' Thesis, Nairobi: University of Nairobi.

Newsome, D., Dowling, R. K., \& Moore, S. A. (2005). Wildlife Tourism (Vol. 24). Chan- 
nel View Publications. https://doi.org/10.21832/9781845410087

Nyhus, P. J., Osofsky, S. A., Ferraro, P., Madden, F., \& Fischer, H. (2005). Bearing the Costs of Human-Wildlife Conflict: The Challenges of Compensation Schemes. Conservation Biology Series-Cambridge, 9, 107. https://doi.org/10.1017/CBO9780511614774.008

Ocholla, G. O., Koske, J., Asoka, G. W., Bunyasi, M. M., Pacha, O., Omondi, S. H., \& Mireri, C. (2013). Assessment of Traditional Methods Used by the Samburu Pastoral Community in Human Wildlife Conflict Management. International Journal of Humanities and Social Science, 3, 292-302.

Oli, M. K., Taylor, I. R., \& Rogers, M. E. (1994). Snow Leopard Panthera uncia Predation of Livestock: An Assessment of Local Perceptions in the Annapurna Conservation Area, Nepal. Biological Conservation, 68, 63-68. https://doi.org/10.1016/0006-3207(94)90547-9

Pack, S., Golden, R., \& Walker, A. (2013). Comparison of National Wildlife Management Strategies: What Works Where, and Why (p. 100). Heinz Center for Science, Economics and the Environment, University of Maryland.

Peterson, M. N., Birckhead, J. L., Leong, K., Peterson, M. J., \& Peterson, T. R. (2010). Rearticulating the Myth of Human-Wildlife Conflict. Conservation Letters, 3, 74-82. https://doi.org/10.1111/j.1755-263X.2010.00099.x

Raini, J. A. (2009). Impact of Land Use Changes on Water Resources and Biodiversity of Lake Nakuru Catchment Basin, Kenya. African Journal of Ecology, 47, 39-45. https://doi.org/10.1111/j.1365-2028.2008.01048.x

Sindiga, I. (1995). Wildlife Based Tourism in Kenya: Land Use Conflicts and Government Compensation Policies over Protected Areas. Journal of Tourism Studies, 6, 45.

Wang, S. W., \& Macdonald, D. W. (2006). Livestock Predation by Carnivores in Jigme Singye Wangchuck National Park, Bhutan. Biological Conservation, 129, 558-565. https://doi.org/10.1016/j.biocon.2005.11.024

Wilkinson, C. E., McInturff, A., Kelly, M., \& Brashares, J. S. (In Review). Quantifying Wildlife Responses to Conservation Fencing in East Africa. 